\title{
Influence of salinity on prevalence of the parasite Loxothylacus panopaei in the xanthid Panopeus obesus in SW Florida
}

\author{
S. Gregory Tolley ${ }^{1, *}$, James T. Winstead ${ }^{2}$, Lesli Haynes ${ }^{1}$, Aswani K. Volety ${ }^{1}$ \\ ${ }^{1}$ Florida Gulf Coast University, Coastal Watershed Institute, 10501 FGCU Boulevard South, Fort Myers, \\ Florida 33965-6565, USA \\ ${ }^{2}$ United States Environmental Protection Agency, National Health and Environmental Effects Research Laboratory, \\ Gulf Ecology Division, 1 Sabine Island Drive, Gulf Breeze, Florida 32561, USA
}

\begin{abstract}
This study was conducted to examine the potential influence of salinity, a proxy for freshwater inflow, on the prevalence of the castrator parasite Loxothylacus panopaei on saltmarsh mud crabs Panopeus obesus on SW Florida oyster reefs. Spatial and seasonal patterns of the presence of potential host crabs and the prevalence of the parasite were assessed in the Caloosahatchee, Estero, and Faka Union estuaries. Lift nets $\left(1 \mathrm{~m}^{2}\right)$ containing $5 \mathrm{l}$ of oyster clusters were deployed on intertidal reefs at 3 sites along the salinity gradient of each estuary. Nets were deployed during 3 seasonally dry and 3 seasonally wet months for a period of $30 \mathrm{~d}$. P. obesus densities tended to increase downstream in higher salinity waters, with crabs being absent from the upper station in the Caloosahatchee during both seasons and absent from the upper station of the Faka Union during wet months. Parasite prevalence was reduced upstream in each estuary during wet months compared to dry months, and for those estuaries that experienced higher relative levels of freshwater inflow. Furthermore, parasite prevalence was positively correlated with the mean salinity of capture of host crabs. Based on the distribution of $P$. obesus and the above patterns related to salinity, it appears that freshwater inflow and seasonal rains might regulate the prevalence of this parasite in SW Florida by creating spatiotemporal, low salinity refuges for its host.
\end{abstract}

KEY WORDS: Loxothylacus panopaei $\cdot$ Panopeus obesus $\cdot$ Xanthidae $\cdot$ Parasite $\cdot$ Salinity

\section{INTRODUCTION}

Barnacles of the family Sacculinidae (Crustacea: Maxillopoda: Cirripedia: Rhizocephala: Kentrogonida; Martin \& Davis 2001) are predominantly marine, shallow-water species (Boschma 1955) that parasitize decapod crustaceans. Among the sacculinids, Loxothylacus panopaei exhibits a generalized host specificity, infecting a number of Western Atlantic and Caribbean species of xanthid crabs, including Dispanopeus sayi, Eurypanopeus depressus, Panopeus lacustris, P. obesus, P. simpsoni and Rhithropanopeus harrisii (Hines et al. 1997). This parasite was first reported from the west coast of Florida (Gissler 1884) and has since become known as 'one of the most common and widely distributed' North American members of the family (Reinhard \& Reischman 1958). Prior to around 1965, its distribution in the Western Atlantic was limited to Gulf of Mexico and Caribbean waters; however, the species was inadvertently transported to Chesapeake Bay via the importation of Gulf of Mexico oysters (and associated mud crabs) in response to declining oyster harvests resulting from the diseases MSX (Haplosporidium nelsoni) and Dermo (Perkinsus marinus) (Andrews \& Hewatt 1957, Van Engel et al. 1965, Andrews 1980, 1996).

The life cycle of the genus Loxothylacus is complex. A female cypris larva settles onto a prospective host and metamorphoses into a kentrogon, capable of penetrating the host's integument (Høeg 1992). An 
interna, which is responsible for the parasite's nutrition (Reisser \& Forward 1991), then develops from embryonic cells injected into the host. The externa subsequently differentiates and emerges onto the abdomen of the host crab, preventing further molting (Walker et al. 1992). Once the externa is inoculated with cells from a male cyprid (Walker et al. 1992), it functions in reproduction and mimics the size and shape of the host species' egg mass (Reisser \& Forward 1991). Rhizocephalan parasites ultimately cause sterilization and feminization (Reisser \& Forward 1991), thus terminating the reproductive output of their hosts.

A number of factors have been suggested as regulating the distribution and prevalence of Loxothylacus panopaei in xanthid crabs. Grosholz \& Ruiz (1995) found that the spatial structure of the host population influenced the prevalence of $L$. panopaei in the mud crab Rhithropanopeus harrisii. These authors proposed that genetic differences in susceptibility might also affect parasite prevalence but found no evidence to support this hypothesis. Van Engel et al. (1965) proposed that temperature might be an important regulating factor, suggesting that the recorded distribution of L. panopaei reflected a preference for warmer waters. Reisser \& Forward (1991) referred to an 'unquantified observation' by one of the authors that the prevalence of $L$. panopaei in $R$. harrisii decreased during summer months with heavy rains, when salinities fell below approximately 15. Based upon subsequent laboratory experiments examining the effects of salinity on parasite survival, these authors concluded that the host $R$. harrisii might find reproductive refuge in estuarine waters below 10 .

The current study was conducted to investigate the influence of salinity on the prevalence of Loxothylacus panopaei in the mud crab Panopeus obesus on SW Florida oyster reefs and to test the hypothesis that low salinity areas within an estuary provide a reproductive refuge for $P$. obesus from this rhizocephalan parasite. Specifically, parasite prevalence was examined among 3 estuaries with differing levels of freshwater inflow, prevalence was compared between seasonally wet and seasonally dry months, and prevalence was compared among sites along the salinity gradient of each estuary. This work also represents the first field-testing of the hypothesized low-salinity reproductive refuge for host crabs (Reisser \& Forward 1991), in this case, P. obesus.

\section{MATERIALS AND METHODS}

Study location. Xanthid crabs, including Panopeus obesus, were collected from oyster reefs in 3 SW Florida estuaries: the Caloosahatchee and Estero rivers and the Faka Union Canal (Fig. 1).
The Caloosahatchee watershed $\left(3700 \mathrm{~km}^{2}\right.$; Science Subgroup 1996, available at http://everglades.fiu.edu/ taskforce/scineeds/sub10.pdf) is both highly altered and highly managed: it was augmented during the late 19th century via the creation of a permanent connection with Lake Okeechobee and the Kissimmee River (Antonini et al. 2002). As part of the Okeechobee Waterway that traverses the state, the upper Caloosahatchee has been converted from a meandering river into a canal over much of its length, and water is impounded behind a series of control structures. Significant freshwater releases into the River from Lake Okeechobee occur both as a means of flood prevention
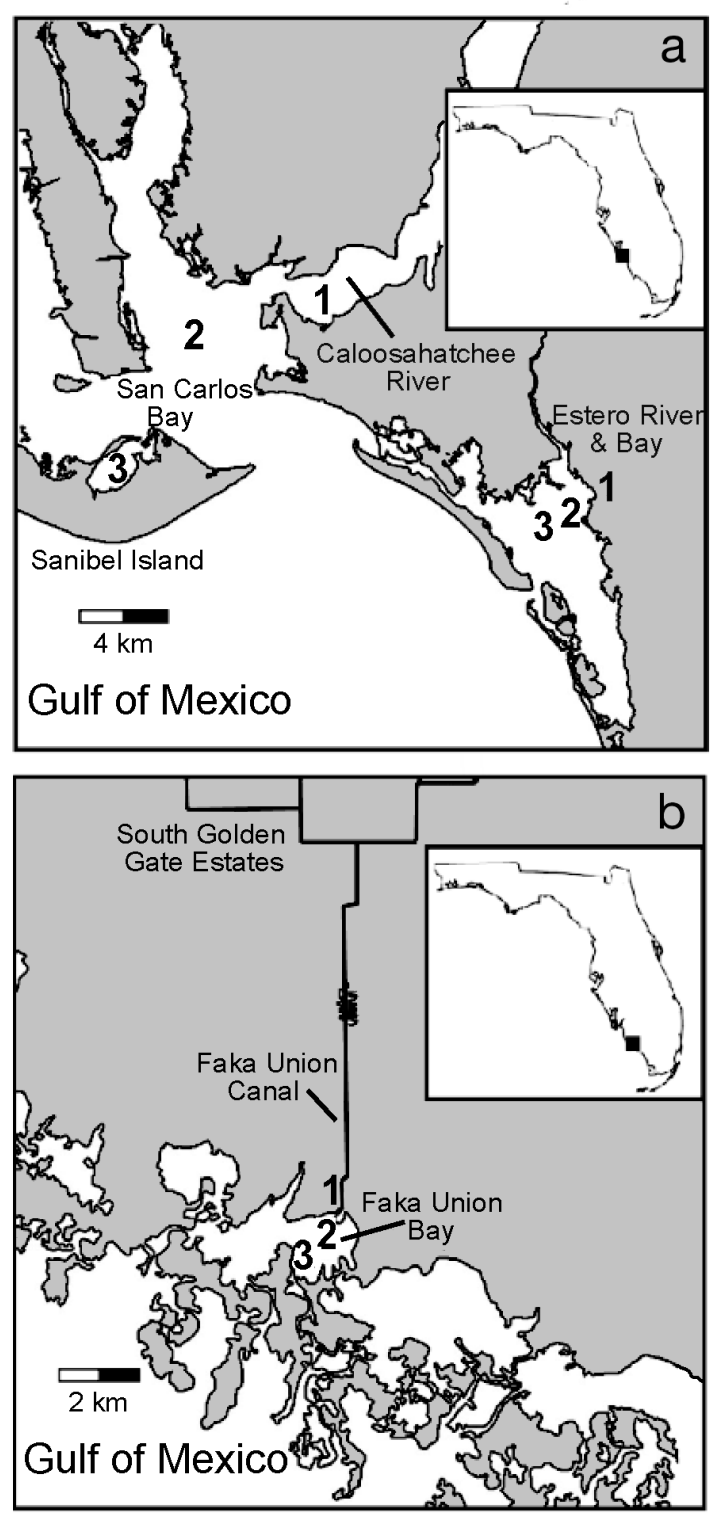

Fig. 1. Study area, showing (a) Caloosahatchee and Estero estuaries and (b) Faka Union estuary. Homologous sampling sites are numbered sequentially from upstream to downstream (1 = upper, 2 = middle, 3 = lower $)$ 
during the rainy season and as a result of periodic drawdowns to manage the lake itself. Lying south of the Caloosahatchee estuary is Estero Bay, the state's first aquatic preserve. Although much of the lower estuary is protected, its tributaries, including the Estero River $\left(170 \mathrm{~km}^{2}\right.$; Janicki 1999, available at www.sfwmd.gov/org/exo/ftmyers/report-text/volb/ ch_3_subbasins.pdf), are being increasingly subjected to development in the upper portions of their watersheds. Farther southeast is the Faka Union Canal that empties into Faka Union Bay, part of the Ten Thousand Islands adjacent to the western boundary of the Everglades National Park. Faka Union $\left(518 \mathrm{~km}^{2}\right.$; Governor's Commission for the Everglades 1999, available at www.state.fl.us/everglades/gcssf/concept/ conc_2c2-11.html) is the least developed of the systems considered, but has a highly augmented watershedthe result of a failed real estate development in the 1960s (i.e. Southern Golden Gate Estates) that created $86 \mathrm{~km}$ of canals in order to drain freshwater wetlands.

Seasons in SW Florida are determined as much by rainfall as by temperature. Seasonal rains are prevalent from mid-June through mid-October and, coupled with occasional tropical weather systems, reduce salinities in local estuaries. In contrast, hypersaline conditions may occur in the downstream portion of these estuaries during the remainder of the year.

Field sampling and analysis. To examine the influence of salinity (freshwater inflow) on the prevalence of the parasite Loxothylacus panopaei, a spatiotemporal comparison of xanthid crabs was conducted during 3 seasonally dry (mid-March through mid-June 2002) and 3 seasonally wet (mid-July through mid-October 2002) months in the 3 estuaries. We selected 3 stations along the salinity gradient of each estuary. Stations were selected at sites that were morphologically homologous among estuaries: an upper station located within the tidal river, a middle station located near the mouth of the river, and a lower station located well below the mouth of the river.

For each sampling effort ( 6 sampling periods $\times 3$ systems $\times 3$ stations), salinity and water temperature were recorded and triplicate lift nets (Crabtree \& Dean 1982) were deployed intertidally just above mean low water on living oyster reefs for a duration of approximately $30 \mathrm{~d}$. An area of bottom approximating $1 \mathrm{~m}^{2}$ was cleared of oyster shell prior to the deployment of each lift net. For more details on lift net construction and deployment see Tolley et al. (2005). Approximately 51 of live oyster clusters were collected from adjacent portions of the reef and were then placed in each net. Upon retrieval of the nets, oyster clusters were removed and associated decapods and fishes were extricated using forceps. Any remaining decapods and fishes were then either removed from the net by hand or by using dip nets to sweep the interior of the lift net. These organisms were then transported on ice back to the laboratory for identification. Specimens were stored in $70 \%$ isopropanol for archiving and further analysis.

In the laboratory, crabs of the family Xanthidae were identified using the descriptions of Williams (1983, 1984), measured to the nearest $0.1 \mathrm{~mm}$ carapace width, and inspected for the presence of externae of the rhizocephalan parasite Loxothylacus panopaei. Parasites were identified using the descriptions of Reinhard \& Reischman (1958) and Overstreet (1978). Parasite presence or absence was noted for each individual and prevalence for each sample was scored as percent infected crabs.

Response variables (e.g. crab density, parasite prevalence, salinity) were examined using 3 -way factorial ANOVA ( 3 estuaries $\times 2$ seasons $\times 3$ stations). Prior to statistical analysis, crab density (individuals $\mathrm{m}^{-2}$ ) was normalized using square root transformation, and parasite prevalence was normalized using arcsine transformation (Zar 1984). Homogeneity of variance was tested using Levene's statistic. Significant differences ( $p \leq 0.05$ ) were resolved using multiple comparison tests according to Day \& Quinn (1989): Fisher's least significant difference in cases of equal sample size and equal variance, Hochberg's GT2 method in cases of unequal sample size but equal variance, and the Games-Howell test in cases of unequal variance. The Pearson correlation coefficient was used to determine the degree of covariance among selected response variables (e.g. parasite prevalence and salinity). For correlation analyses involving salinity or temperature, mean values were calculated from measurements made at the beginning and end of each lift-net deployment. All missing values were excluded from analysis, and unless otherwise stated data are presented in their original (untransformed) units as mean \pm SE. Statistical analyses were performed using SPSS $^{\circledast}$ 11.0 software.

\section{RESULTS}

\section{Parasite hosts}

Flatback mud crabs Eurypanopeus depressus, knotfinger mud crabs Panopeus lacustris, saltmarsh mud crabs $P$. obesus and oystershell mud crabs $P$. simpsoni were all collected from SW Florida oyster reefs and were all found to be parasitized by Loxothylacus panopaei (Table 1). Although E. depressus dominated xanthid samples, parasite prevalence was low $(<1 \%)$ regardless of estuary. In contrast, overall parasite prevalence was moderate in P. lacustris (9.1 to 
Table 1. Eurypanopeus depressus and Panopeus spp. Total numbers of mud crabs collected on oyster reefs in 3 SW Florida estuaries. Numbers in parentheses: prevalence (\%) of parasite Loxothylacus panopaei

\begin{tabular}{|lrrrr|}
\hline \multirow{2}{*}{ Species } & \multicolumn{3}{c}{ Estuary } & \multirow{2}{*}{ Total } \\
\cline { 2 - 4 } & Caloosahatchee & \multicolumn{1}{c}{ Estero } & Faka Union & \\
\hline E. depressus & $3425(0.06)$ & $2648(0.53)$ & $3040(0.03)$ & $9113(0.19)$ \\
P. lacustris & $11(9.09)$ & $5(20.00)$ & $14(14.29)$ & $30(20.00)$ \\
P. obesus & $75(6.67)$ & $155(33.55)$ & $203(4.93)$ & $433(15.47)$ \\
$P$. simpsoni & $14(21.43)$ & $18(50.00)$ & $4(25.00)$ & $36(36.11)$ \\
\hline
\end{tabular}

$20.0 \%$ ) and P. simpsoni (21.4 to $50.0 \%$ ); however, relatively few individuals of these species were taken from each estuary sampled (Table 1). Only $P$. obesus occurred in large enough numbers and exhibited high enough levels of parasite prevalence to be considered for further analysis.

\section{Mud crab density}

Results of ANOVA indicated significant main (estuary, season and station) and interaction effects on Panopeus obesus density (Table 2). Regarding main effects, $P$. obesus densities were significantly lower in the Caloosahatchee $\left(1.4 \pm 0.3\right.$ individuals $\left.\mathrm{m}^{-2}\right)$ compared to either the Estero $\left(3.0 \pm 0.3\right.$ individuals $\left.\mathrm{m}^{-2}\right)$ or Faka Union $\left(3.7 \pm 0.3\right.$ individuals $\left.\mathrm{m}^{-2}\right)(F[2,137]=16.7$, $\mathrm{p}<0.001)$; densities were higher during the dry season $\left(3.6 \pm 0.2\right.$ individuals $\left.\mathrm{m}^{-2}\right)$ compared to wet months $\left(1.9 \pm 0.2\right.$ individuals $\left.\mathrm{m}^{-2}\right)(F[1,137]=27.5 . \mathrm{p}<0.001)$; and densities increased downstream among stations $(F[2,137]=101.0, p<0.001)$. Examining the estuary $\times$ station interaction $(F[4,137]=32.6, \mathrm{p}<0.001)$, density was significantly lower at the upper station compared to those downstream in the Caloosahatchee and was significantly lower at the upper and middle stations compared to the lower station in both the Estero and Faka Union (Fig. 2). The season $\times$ station interaction $(F[2,137]=7.7, \mathrm{p}=0.001)$ indicated that the trend of increasing $P$. obesus density from upper to lower stations was persistent regardless of season. No significant estuary $\times$ season interaction was detected.

\section{Parasite prevalence}

Of the 433 Panopeus obesus collected $(17.8 \mathrm{~mm} \pm 7.7 \mathrm{SD}), 67$ were infected with the parasite Loxothylacus panopaei for an overall prevalence of $15.5 \%$ (Table 1). Significant spatial and temporal variation in the prevalence of the parasite L. panopaei was detected using ANOVA (Table 3). Parasite prevalence was lower in Faka Union $(2.1 \pm 1.2 \%)$ than in Estero $(27.0 \pm 5.4 \%)(F[2,92]=10.6, \mathrm{p}<0.001)$, and overall was lower in the wet season $(9.0 \pm 3.6 \%)$ compared to dry months $(18.8+4.1 \%)(F[1,92]=4.9, \mathrm{p}=0.029)$. Although the effect of station on parasite prevalence was marginally significant $(F[2,92]=3.1, \mathrm{p}=0.049)$, the Games-Howell multiple comparison test was unable to detect any differences. No interaction effects for any of the above factors were deemed statistically significant.

Upon further examination of the data using 1-way ANOVA, some station effects were detected. In the Caloosahatchee, prevalence was significantly lower at the middle station than the lower station during the dry season (Fig. 3), and went to zero at both the middle and lower stations during the wet season (Fig. 3). No Panopeus obesus were collected from the upper station during either season in the Caloosahatchee. In the Faka Union, parasite prevalence was zero at both the upper and middle stations during the dry season, with no among-station differences being detected; during wet months, parasite prevalence dropped to zero at the lower station as well, and no P. obesus were collected from the upper station. No significant differences in parasite prevalence were detected in the Estero for either season, although prevalence dropped to zero at the upper station during wet months.
Table 2. Panopeus obesus. Analysis of variance (general linear model) examining density (numbers $\mathrm{m}^{-2}$ ). Data transformed using $\sqrt{X+1}$ prior to analysis. Estuary: Caloosahatchee, Estero, Faka Union; Season: dry, wet; Station: upper, middle, lower

\begin{tabular}{|lrrrr|}
\hline Source & df & MS & \multicolumn{1}{c|}{$F$} & p-value \\
\hline Estuary & 2 & 3.117 & 16.679 & $<0.001$ \\
Season & 1 & 5.147 & 27.538 & $<0.001$ \\
Station & 2 & 18.873 & 100.982 & $<0.001$ \\
System $\times$ Season & 2 & 0.050 & 0.295 & 0.745 \\
System $\times$ Station & 4 & 6.103 & 32.656 & $<0.001$ \\
Season $\times$ Station & 2 & 1.435 & 7.679 & 0.001 \\
System $\times$ Season $\times$ Station & 4 & 1.095 & 5.857 & $<0.000$ \\
\hline
\end{tabular}

\section{Environmental factors}

Significant main effects on salinity were detected for estuary, season and station. Mean salinity was higher in the Estero (30.90 \pm 1.43$)$ compared to either the Caloosahatchee $(24.28 \pm 1.32)$ or Faka Union $(20.93 \pm 1.32)(F[2,51]=14.6$, $\mathrm{p}<0.001$ ); salinity was higher during the dry season $(33.77 \pm 1.14)$ compared to wet months $(16.96 \pm 1.08)(F[1,51]=$ $114.5, \mathrm{p}<0.001)$; and salinity was signif- 

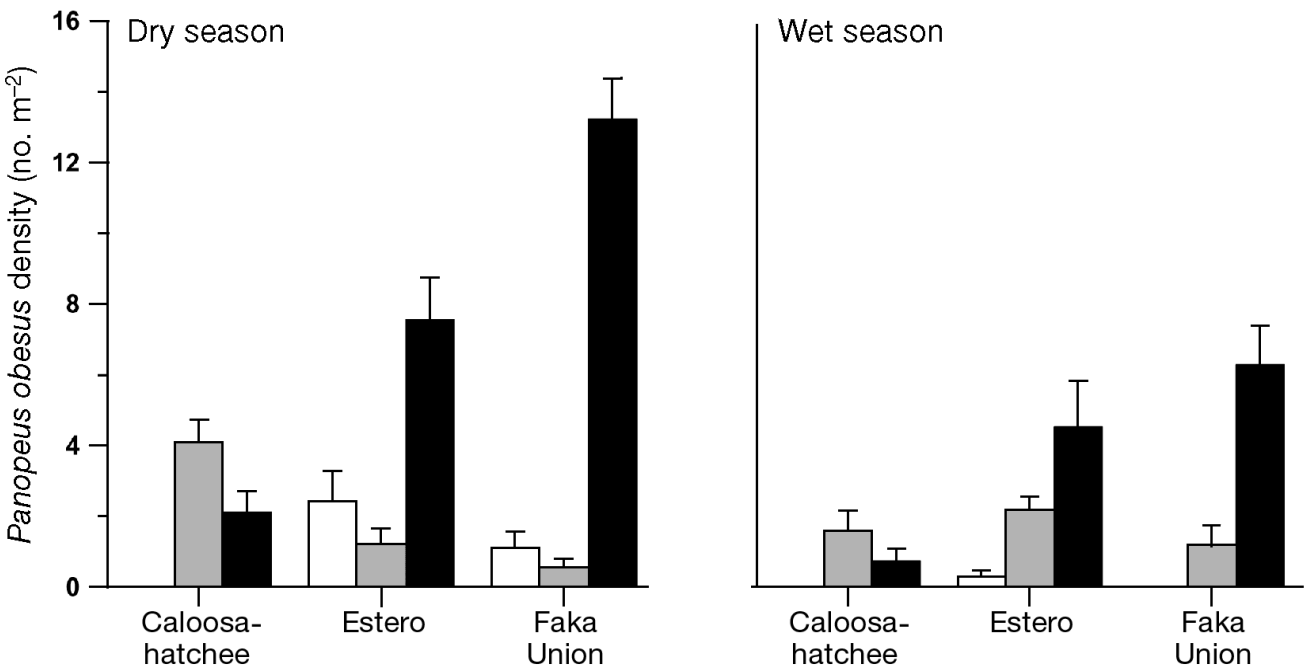

Fig. 2. Panopeus obesus. Spatiotemporal differences in densities of mud crabs collected from oyster reefs in 3 SW Florida estuaries. Untransformed means (+SE) (stations = open, upper; gray, middle; black, lower)

icantly higher at the lower station $(30.20 \pm 1.36)$ compared to the upper station $(19.99 \pm 1.36)(F[2,51]=14.2$, $\mathrm{p}<0.001)$. Upon examination of interaction effects it was clear that salinity was higher during the dry season regardless of system (Fig. 4). Furthermore, salinity increased significantly downstream in the Caloosahatchee and was higher at the lower station than at the upper station in Faka Union (Fig. 4); however, these patterns were significant only during the wet season. No among-station differences in salinity were detected in the Estero.

Water temperature was higher during the wet season $\left(29.03 \pm 0.60^{\circ} \mathrm{C}\right)$ compared to dry months $(27.25 \pm$ $\left.0.52^{\circ} \mathrm{C}\right)(F[1,54]=14.7, \mathrm{p}<0.001)$. No system, station, or interaction effects were detected.

Correlation analysis using data from all 3 estuaries revealed a significant positive relationship between parasite prevalence and salinity (Fig. 5). In contrast, parasite prevalence was inversely related to temperature $(\mathrm{r}=$ $-0.43, \mathrm{p}=0.024, \mathrm{n}=27$ ), which was higher during seasonally wet months when salinities were reduced. Loxothylacus panopaei prevalence was not correlated with either mean size or density of Panopeus obesus.

Table 3. Panopeus obesus parasitized by Loxothylacus panopaei. Analysis of variance (general linear model) examining incidence of parasitism of $L$. panopaei on mud crab $P$. obesus. Data arcsine-transformed prior to analysis. Estuary: Caloosahatchee, Estero, Faka Union; Season: dry, wet; Station: upper, middle, lower

\begin{tabular}{|lccrr|}
\hline Source & df & MS & $F$ & p-value \\
\hline Estuary & 2 & 5381.797 & 10.679 & $<0.001$ \\
Season & 1 & 2516.797 & 4.947 & 0.029 \\
Station & 2 & 1589.176 & 3.124 & 0.049 \\
\hline
\end{tabular}

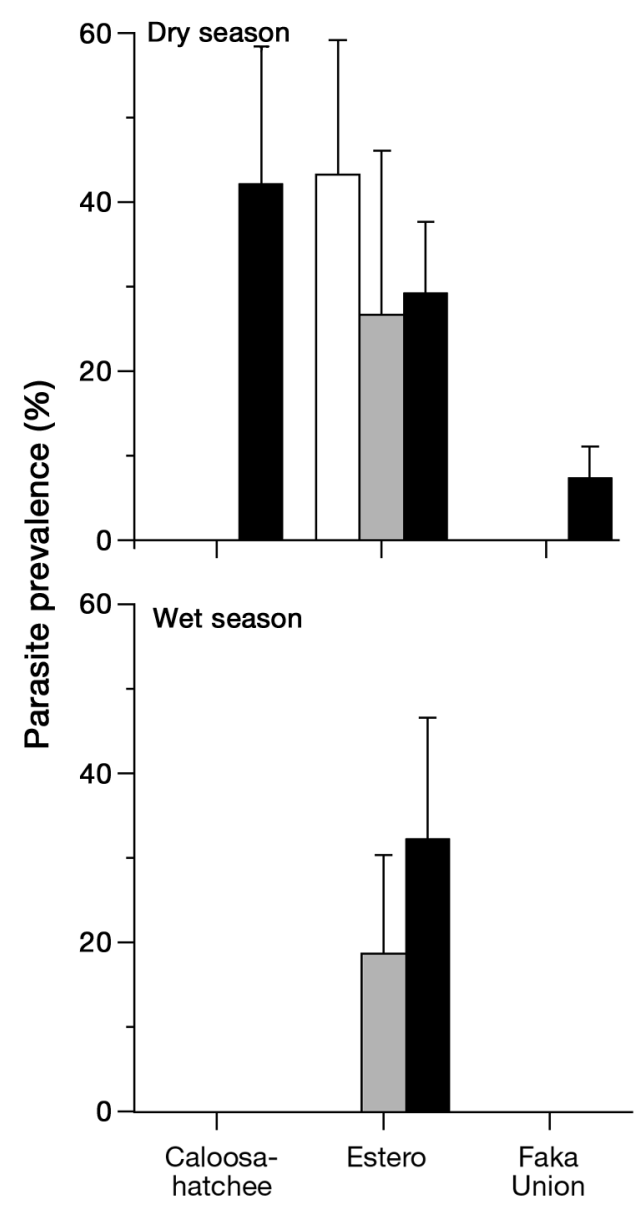

Fig. 3. Panopeus obesus parasitized by Loxothylacus panopaei. Spatiotemporal differences in prevalence of parasite in mud crabs collected from oyster reefs in 3 SW Florida estuaries. Untransformed means (+SE) (stations = open, upper; gray, middle; black, lower). No P. obesus were collected from upper station in Caloosahatchee 

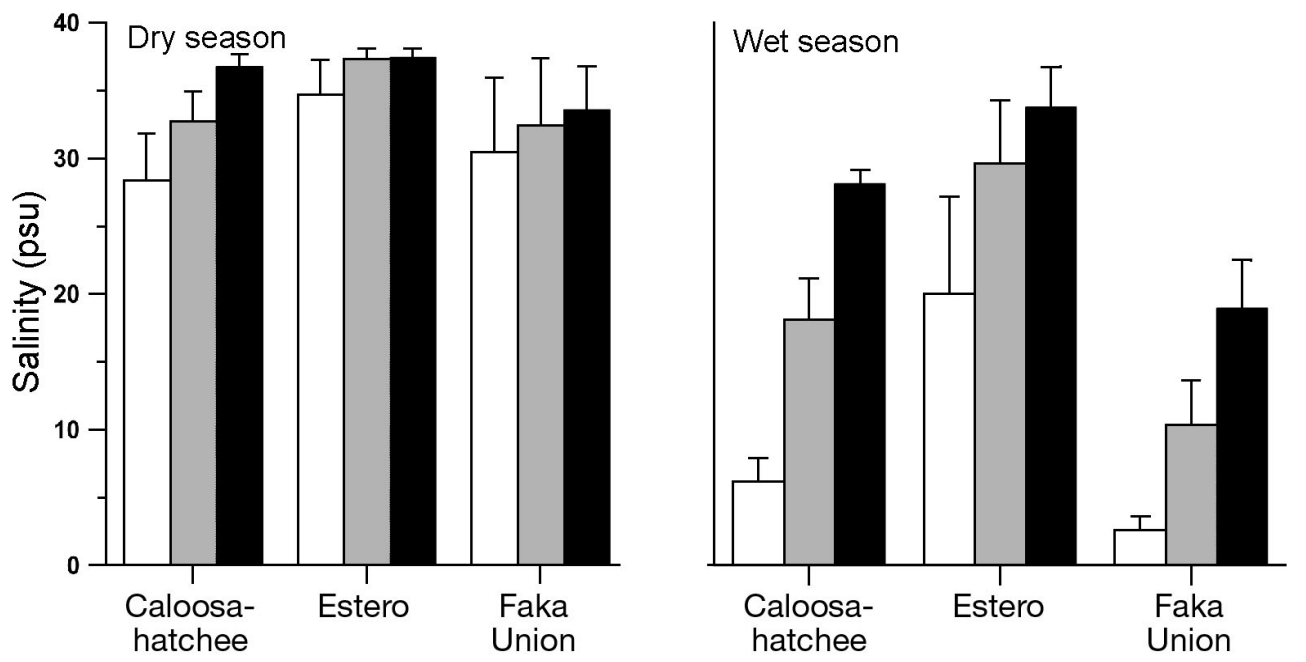

Fig. 4. Spatiotemporal differences in salinity at oyster reefs in 3 SW Florida estuaries. Untransformed means (+SE) (stations = open, upper; gray, middle; black, lower)

\section{DISCUSSION}

Prevalence of the parasite Loxothylacus panopaei on the mud crab Panopeus obesus in the Caloosahatchee $(6.7 \%)$ and Faka Union $(4.9 \%)$ estuaries was similar to the values of 0 to $4.3 \%$ previously reported for $P$. obesus in the NE Gulf of Mexico (Hines et al. 1997). These levels contrast with the higher degree of parasitism (33.6\%) found for P. obesus in Estero Bay as well as for both $P$. lacustris and $P$. simpsoni found in all 3 estuaries. The xanthid Eurypanopeus depressus was also found to be infected with $L$. panopaei; however, para-

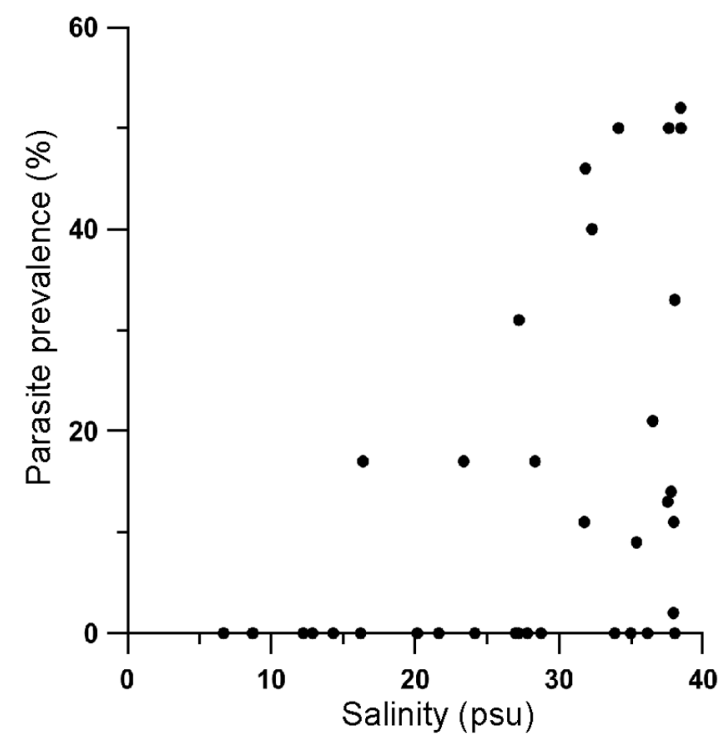

Fig. 5. Panopeus obesus. Relationship between parasite (Loxothylacus panopaei) prevalence and mean salinity of capture of host crabs for all 3 estuaries (arcsine-transformed parasite prevalence: $\mathrm{r}=0.57, \mathrm{p}<0.001, \mathrm{n}=45$ ) site prevalence was consistently low $(<1 \%)$ regardless of the estuary examined. Hines et al. (1997) reported prevalences as high as $83.3 \%$ for E. depressus in Virginia waters but noted that prevalence in Florida populations of this mud crab 'was very low to nil'.

The results of the current study suggest that salinity may play a role in regulating the distribution and prevalence of the rhizocephalan parasite Loxothylacus panopaei in Panopeus obesus. Evidence from all 3 estuaries suggests that parasite prevalence was reduced upstream during seasonally wet months, when salinity gradients were more fully expressed. It is important to note that the comparison of parasite prevalence among stations was complicated by the fact that $P$. obesus densities also tended to decrease upstream. In fact, no $P$. obesus were found at the upper station in the Caloosahatchee, regardless of season, and none were found at the upper station in the Faka Union during the wet season.

Parasite prevalence was also significantly lower during wet months, when salinities were reduced and overall prevalence was lower in the Caloosahatchee and Faka Union compared to Estero Bay. These estuaries possess highly augmented watersheds and therefore experience a much greater degree of seasonal freshwater inflow than does Estero Bay. Further evidence for a relationship between parasite prevalence and salinity is provided in the form of the significant positive correlation found between prevalence and mean salinity of capture for host crabs.

Reisser \& Forward (1991) conducted a series of experiments to determine salinity tolerance in this parasite. Loxothylacus panopaei nauplii and cypris acclimated to 15 exhibited decreased survival at both lower (5) and higher (20) salinities compared to 10-15, leading the 
authors to propose that 'salinity tolerance of parasite larvae controlled the parasite's distribution'. These authors also suggested that because the salinity distribution of the host Rhithropanopeus harrisii (0 to 19, Ryan 1956) was not coincident with the optimal salinity range of the parasite (10 to 15), crabs might seek reproductive refuge in waters of salinities $<10$ or $>15$.

Walker \& Clare (1994) examined the influence of salinity on the development and survival of Loxothylacus panopaei larvae using broods from parasitized Rhithropanopeus harrisii acclimated at both 10 and 20. Their results supported the hypothesis that crabs might find refuge at salinities below 10, but did not support the potential for refuge at higher salinities. Tindle et al. (2004) investigated the effects of salinity on Loxothylacus texanus, a parasite of the blue crab Callinectes sapidus. These authors concluded that 'nauplii of the rhizocephalan genus, Loxothylacus, are not well adapted to low (<15 ppt) salinity habitats' and that at the cypris stage $L$. texanus larvae might be unable to complete metamorphosis to the kentrogon stage if exposed to an acute reduction in salinity from 25 to 10 . Tindle et al. (2004) suggested that parasite prevalence 'could be influenced by local rainfall patterns, particularly in shallow estuaries' - a conclusion consistent with the results of the present study.

If, then, the lower salinities in the upper reaches of estuaries provide refuge for xanthids from infection by Loxothylacus panopaei, is Panopeus obesus able to take advantage of such safe havens? Field studies suggest that the genus Panopeus tends to be found in greater abundance at higher salinities. In the present study, $P$. obesus density increased downstream, and the species was often absent from the uppermost stations sampled. Reames \& Williams (1983) reported that $P$. obesus from Alabama waters were not found in salinities <14. Similarly, Ryan (1956) collected P. herbstii from salinities of 14 to 19 in Chesapeake Bay, and Schwartz \& Cargo (1960) collected the species at salinities of 10 to 34 in Chesapeake and Chincoteague Bays.

Data regarding salinity tolerance of Panopeus obesus are lacking; however, such data are available for its congener $P$. herbstii. Dimock \& Groves (1975) demonstrated, over a range of acclimation salinities, a general increase in oxygen consumption by $P$. herbstii in response to decreased salinity. Blasco \& Forward (1988) reported that the species is a hyperosmotic regulator at salinities below 28 and an osmoconfomer at higher salinities, and is capable of quick adjustment to hypoosmotic shock. Shumway (1983) reported a sharp increase in oxygen consumption rate of $P$. herbstii subjected to reduced salinities (0 to $40 \%$ seawater) and noted that, although the species is highly tolerant of reduced salinities, it is most often found in higher salinities. If physiological responses of $P$. obesus are similar to those recorded for $P$. herbstii in laboratory settings, then the absence of $P$. obesus from the upper stations in this study as well as reductions in density associated with the wet season may reflect emigration rather than mortality.

Loxothylacus panopaei is capable of parasitizing not only adult xanthids but also post larvae and juveniles (Walker et al. 1992). It is therefore important to consider the distribution along the estuary of all lifehistory stages susceptible to infection. Compared to adults, there is some indication that Panopeus herbstii larvae are also associated with higher salinities. Sandifer (1973) reported that less than $5 \%$ of the $P$. herbstii larvae collected from the York River estuary and lower Chesapeake Bay were collected from salinities $<15$, and Costlow et al. (1962) found that larval development does not occur at 12.5 compared to higher salinities. Furthermore, McKenney \& Costlow (1981) found that lower salinities resulted in lower survival and in increased duration of larval development.

Based on inferred salinity tolerance and reported distribution along salinity gradients, it is difficult to argue that low salinity waters provide reproductive refuge for Panopeus obesus to the extent postulated for Rhithropanopeus harrisii. $R$. harrisii is frequently found in the upper reaches of an estuary in waters that are suboptimal for the survival and development of Loxothylacus panopaei larvae. In contrast, P. obesus tends to occupy higher salinity waters where $L$. panopaei appears to do quite well. Nonetheless, the results of this study suggest that reduced salinities do play a role in the regulation of this rhizocephalan parasite in SW Florida. Reduced salinities, whether occurring in the upper reaches of the estuary or during summer months as a result of seasonal rains, were associated with decreased prevalence of $L$. panopaei. Furthermore, parasite prevalence was reduced in those estuaries experiencing lower salinities resulting from greater relative freshwater inflow. These patterns, coupled with the known geographic distribution of $P$. obesus in relation to salinity, indicate that freshwater inflow may regulate the prevalence of the parasite L. panopaei in SW Florida estuaries, creating spatiotemporal refuges for successful reproduction by potential host crabs.

Acknowledgements. We thank P. Doering, T. Barnes and A. Nath of the South Florida Water Management District (SFWMD) for their support and advice. We are also grateful to $\mathrm{R}$. Totaro for her careful review of the manuscript. S. Thurston and E. Dykes coordinated sampling and analysis and a small army of undergraduate students contributed significantly to the field and laboratory work: B. Andrews, S. Bankston, M. Chichester, J. Farineau, R. Grindberg, M. Hooper, B. Jacobs, C. Jauzein, E. Lindland, C. Linardich, C. Loret, A. Ruttan, L. Smith and J. Standiford. Many of these students were sup- 
ported by Congressional Grant P116Z010066 awarded through the US Department of Education. This work was supported by SFWMD grants C-12412-A1 and C-13252 and by an internal grant to the first author from Florida Gulf Coast University.

\section{LITERATURE CITED}

Andrews JD (1980) A review of introductions of exotic oysters and biological planning for new importations. Mar Fish Rev 42:1-11

Andrews JD (1996) History of Perkinsus marinus, a pathogen of oysters in Chesapeake Bay 1950-1984. J Shellfish Res 15:13-16

Andrews JD, Hewatt WG (1957) Oyster mortality studies in Virginia. II. The fungus disease caused by Dermocystidium marinum in oysters of Chesapeake Bay. Ecol Monogr 27:1-25

Antonini GA, Fann DA, Roat P (2002) A historical geography of SW Florida waterways. Vol 2, Placida Harbor to Marco Island. Florida Sea Grant, Gainesville, FL

Blasco E, Forward RB Jr (1988) Osmoregulation of the xanthid crab, Panopeus herbstii. Comp Biochem Physiol A 90: 135-139

Boschma H (1955) The described species of the family Sacculinidae. Zool Verh 27:1-76

Costlow JD Jr, Bookhout CG, Monroe R (1962) Salinitytemperature effects on the larval development of the crab Panopeus herbstii Milne-Edwards, reared in the laboratory. Physiol Zool 35:79-93

Crabtree RE, Dean JM (1982) The structure of two South Carolina estuarine tide pool fish assemblages. Estuaries 5:2-9

Day RW, Quinn GP (1989) Comparisons of treatments after an analysis of variance in ecology. Ecol Monogr 59:433-463

Dimock RV Jr, Groves KH (1975) Interaction of temperature and salinity on oxygen consumption of the estuarine crab Panopeus herbstii. Mar Biol 33:301-308

Gissler CF (1884) The crab parasite, Sacculina. Am Nat 18: $225-229$

Grosholz ED, Ruiz GM (1995) Does spatial heterogeneity and genetic variation in populations of the xanthid crab Rhithropanopeus harrisii (Gould) influence the prevalence of an introduced parasitic castrator? J Exp Mar Biol Ecol 187:129-145

Hines AH, Alvarez F, Reed SA (1997) Introduced and native populations of a marine parasitic castrator: variation in prevalence of the rhizocephalan Loxothylacus panopaei in xanthid crabs. Bull Mar Sci 61:197-214

Høeg JT (1992) Chapter 6: Rhizocephala. In: Humes AG (ed) Microscopic anatomy of invertebrates. Vol 9. Crustacea. Wiley-Liss, New York, p 313-345

Martin JW, Davis GE (2001) An updated classification of the recent Crustacea. Nat Hist Mus Los Angel Cty Sci Ser 39

McKenney C, Costlow JD (1981) The effect of salinity and mercury on the larval development of Panopeus herbstii Milne-Edwards. In: Vaskovskij VE, Vernberg FJ, Zhir-

Editorial responsibility: Timothy Flegel,

Bangkok, Thailand munskij AV (eds) Pacific Science Congress 14, Khabarovsk, USSR, Section Marine Biology, Issue 3: Physiology and biochemistry of adaptation in marine animals. Inst Biologii Morya, Vladivostok, p 114-128

Overstreet RS (1978) Marine maladies? Worms, germs and other symbionts from the northern Gulf of Mexico. Publ. MASGP-78-021. Sea Grant Consortium, Mississippi, AL

Reames RC, Williams AB (1983) Mud crabs of the Panopeus herbstii HM EDW, SL, complex in Alabama, USA. Fish Bull 81:885-890

Reinhard EG, Reischman PG (1958) Variation in Loxothylacus panopaei (Gissler), a common sacculinid parasite of mud crabs, with the description of Loxothylacus perarmatus, n. sp. J Parasitol 44:93-97

Reisser CE, Forward RB Jr (1991) Effect of salinity on osmoregulation and survival of a rhizocephalan parasite, Loxothylacus panopaei, and its crab host, Rhithropanopeus harrisii. Estuaries 14:102-106

Ryan EP (1956) Observations on the life histories and the distribution of the Xanthidae (mud crabs) of Chesapeake Bay. Am Midl Nat 56:138-162

Sandifer PA (1973) Distribution and abundance of decapod crustacean larvae in the York River estuary and adjacent lower Chesapeake Bay, Virginia, 1968-1969. Chesapeake Sci 14:235-257

Schwartz FJ, Cargo DG (1960) Recent records of the xanthid crab, Panopeus herbstii, from Maryland and Virginia waters. Chesapeake Sci 3-4:201-202

Shumway SE (1983) Oxygen consumption and salinity tolerance in four Brazilian crabs. Crustaceana 44:76-82

Tindle S, Boone E, O'Brien J, Boettcher A (2004) Effects of salinity on larval stages of the rhizocephalan barnacle Loxothylacus texanus: survival and metamorphosis in response to the host. Callinectes sapidus. J Exp Mar Biol Ecol 302:165-176

Tolley SG, Volety AK, Savarese M (2005) Influence of salinity on habitat use of oyster reefs in three SW Florida Estuaries. J Shellfish Res 24:127-137

Van Engel WA, Dillon WA, Zwerner D, Eldridge D (1965) Loxothylacus panopaei (Cirripedia, Sacculinidae), an introduced parasite on a xanthid crab in Chesapeake Bay, USA. Crustaceana 10:111-112

Walker G, Clare AS (1994) The effect of salinity on the development of Loxothylacus panopaei larvae (Crustacea: Cirripedia: Rhizocephala). Estuaries 17:276-282

Walker G, Clare AS, Rittschof D, Mensching D (1992) Aspects of the life-cycle of Loxothylacus panopaei (Gissler), a sacculinid parasite of the mud crab Rhithropanopeus harrisii (Gould): a laboratory study. J Exp Mar Biol Ecol 157: 181-193

Williams AB (1983) The mud crab, Panopeus herbstii, SL partition into six species (Decapoda: Xanthidae). Fish Bull 81:863-882

Williams AB (1984) Shrimps, lobsters, and crabs of the Atlantic coast of the eastern United States, Maine to Florida. Smithsonian Institution Press, Washington, DC

Zar JH (1984) Biostatistical analysis, 2nd edn. Prentice Hall, Englewood Cliffs, NJ

Submitted: September 22, 2005; Accepted: February 13, 2006 Proofs received from author(s): June 13, 2006 